\title{
CHEMICAL COMPOSITION AND ALLELOPATHYC ACTIVITY OF ESSENTIAL OIL OF Lippia sidoides Cham.
}

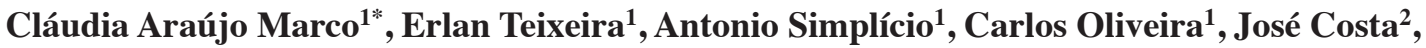 \\ and José Feitosa ${ }^{1}$
}

\begin{abstract}
The allelopathy is a process for which products of the secondary metabolism, as terpenes phenolic, of a certain vegetal intervene significantly, generally of antagonistic form, in the development of other species of plants. The objective of this work was to chemically characterize the essential oil of Lippia sidoides Cham. growing in the Cariri cearense region, Brazil, and evaluate the allelopathyc effect of this oil on the germination of lettuce (Lactuca sativa L.), arugula (Eruca sativa Mill.), and cauliflower (Brassica oleracea L.), in pre-plantation application. The monoterpene thymol (84.90\%) has been identified as the principal constituent in the essential oil. The experiment was done in randomized complete block, in $4 \times 3$ factorial; being used four essential oil combinations applied in three different species in pre-plantation applications. Emergence velocity index (EVI), germination percentage and mean time to germination (MTG), had been analyzed through daily counting carried out until the $14^{\text {th }}$ day after sowing. Through qualitative analysis performed by gas chromatography coupled with mass spectrometry (GC/MS) were identified seven chemical constituents representing $97.82 \%$ of essential oil of $L$. sidoides, being that the constituent present in greater concentration in oil was the thymol (84.90\%). Could be verified the occurrence of the negative allelopathyc effect of lettuce crop, because its present low EVI and greater MTG, for the other vegetable species there were no allelopathic effect.
\end{abstract}

Key words: Allelopathy, plant oil, Lippia sidoides, Lactuca sativa, Eruca sativa, Brassica oleracea.

$\mathrm{T}$ he plants compete for light, water, and nutrients, revealing a constant competition between the species living in community. This contributes to the survival of species in the ecosystem, and some develop defense mechanisms that rely on synthesis of certain secondary metabolites, released into the environment and which will interfere in some stage of the lifecycle of other plant (Alves et al., 2004). The allelopathy is a biochemical interaction mechanism between plants, being considered a form of defensive chemical adaptation of plants, in addition to being an environmental stress factor for many plants. Available information shows that chemical substances with allelopathic activity are present in all organs of plants (Alves et al., 2002).

Allelopathic effects are mediated by substances belong to different categories of secondary compounds. Recent advances in natural products chemistry, by means of modern methods of extraction, isolation, purification and identification, have contributed greatly to a better

${ }^{1}$ Universidade Federal do Ceará UFC, Curso de Agronomia, Campus Cariri, Av. Tenente Raimundo Rocha, S/N Bairro Cidade Universitária-63.040-370, Juazeiro do Norte, Ceará, Brasil. *Corresponding author (clmarko@ufc.br).

${ }^{2}$ Universidade Regional do Cariri URCA, Programa de PósGraduação em Bioprospecção Molecular, Departamento de Química Biológica, Rua Cel. Antônio Luiz 1161, Pimenta, 63105-000 Crato, Ceará, Brasil.

Received: 6 April 2011.

Accepted: 22 November 2011. knowledge of these secondary compounds, which can be grouped in various ways (Ferreira and Áquila, 2000). The volatile terpenes, components of essential oils, show important allelopathic action. The great interest in the study of plants with possible allelopathic effect is justified by the increasing need to develop a sustainable agriculture, while reducing environmental damage and to human health provoked by the introduction of chemical compounds, and find alternatives to the use of synthetic herbicides. Over the last $10 \mathrm{yr}$, some studies have assigned various properties to Lippia sidoides Cham., especially to its essential oil: larvicide (Carvalho et al., 2003), antimicrobial (Botelho et al., 2007) and cytotoxic (Costa et al., 2001).

This work has as objective to characterize chemically the essential oil of L. sidoides grown in the region of Cariri cearense and assess the allelopathic effect of $L$. sidoides over the germination of lettuce (Lactuca sativa L.), eruca (Eruca sativa Mill.) and cauliflower (Brassica oleracea L.) under pre-planting applications.

\section{MATERIALS AND METHODS}

\section{Obtaining the essential oil}

Essential oils extracted from fresh leaves of $L$. sidoides (100 g) were obtained by hydro-distillation, using the appliance type Clevenger, for a period of $2 \mathrm{~h}$. Then the oil/ water mixture was collected, dried with anhydrous sodium sulfate $\left(\mathrm{Na}_{2} \mathrm{SO}_{4}\right)$, filtered and stored under refrigeration until analyses. 
Analysis of chemical composition of the essential oil Analyses of chemical compositions were performed using a spectrometer Shimadzu CG-17A/EM QP5050A utilized system gas chromatography coupled with mass spectrometry (GC/MS): DB-5HT capillary column (30 m $\times 0.251 \mathrm{~mm}$ ); gas carrier: helium $1.7 \mathrm{~mL} \mathrm{~min}^{-1}$; pressure column $107.8 \mathrm{kPa}$; linear velocity $=47.3 \mathrm{~cm} \mathrm{~s}^{-1}$; total flow $24 \mathrm{~mL} \mathrm{~min}^{-1}$; flow carrier $24 \mathrm{~mL} \mathrm{~min}^{-1}$; injector temperature $270{ }^{\circ} \mathrm{C}$; detector temperature $290^{\circ} \mathrm{C}$; column temperature $60{ }^{\circ} \mathrm{C}(2 \mathrm{~min})-180^{\circ} \mathrm{C}(1 \mathrm{~min})$ to $4{ }^{\circ} \mathrm{C} \mathrm{min}^{-1}$, then $180-260$ ${ }^{\circ} \mathrm{C}$ to $10{ }^{\circ} \mathrm{C} \mathrm{min}^{-1}$ (10 $\mathrm{min}$ ). Operating ionization energy was $70 \mathrm{eV}$.

The identification of components was based on spectral fragmentation, using library patterns from computer Wiley 229, plus two other arguments: retention index and comparison with data from literature (Alencar et al., 1990; Adams, 2001).

\section{Evaluation of allelopathic activity}

The experiment was performed in the greenhouse of Biology Laboratory of the campus of the Federal University of Ceará in Cariri. Plastic trays, containing sterilized washed sand, were moist with different solutions contain different concentrations of $L$. sidoides essential oil ( 0.25 , 0.5 , and $1.0 \mathrm{~mL} \mathrm{~L}^{-1}$ ) and control with only distilled water. After 24 h, 25 seeds (repetitions) were sowed in each tray per species. Each tray received two watering daily. The verification of the allelopathic effect of the essential oil in the different concentrations was made by evaluation of emergency velocity index (EVI), germination percentage (GP), and mean time to germination (MTG). Seeds that showed radicle protrusion were considered germinated. The counting was made until the $14^{\text {th }}$ day.

It was used a randomized complete blocks design, in 4 $\times 3$ factorial; four combinations of essential oil, in three different species (lettuce, arugula, and cauliflower) under pre-planting application, with three repetitions for each treatment and 36 parcels ( 36 plastic trays). The ANOVA was done by application of Test $\mathrm{F}$ with $5 \%$ probability, and when significance was observed, the variables averages were compared by the Tukey test $(\mathrm{P}<0.05)$.

\section{RESULTS AND DISCUSSION}

The yield of L. sidoides oil extracted from the fresh leaves was high, presenting a value of $2.14 \%$, performance like a plant with a high production of essential oil. The system gas chromatography coupled with mass spectrometry (GC/MS) analysis of essential oil has allowed the identification of seven chemical constituents representing $97.82 \%$ of the essential oil: six monoterpenes and one sesquiterpene. It was even possible to identify that from these monoterpenes, four were oxygenated $(1,8$-cineole, carvacrol-methyl ether, thymol and carvacrol) (Table 1). Silva et al. (2010) analyzing the essential oil of Origanum vulgare L.e Morais et al. (2011) studying the oil of Conobea
Table 1. Chemical components of Lippia sidoides fresh leaves essential oil. Juazeiro do Norte, Ceará.

\begin{tabular}{lccr}
\hline Components & RT (min) & $\mathrm{KI}^{*}$ & $(\%)$ \\
\hline$p$-Cymene & 4.2 & 1020 & 5.33 \\
1,8-Cineole & 4.4 & 1031 & 1.68 \\
$\gamma$-Terpinene & 5.0 & 1060 & 1.32 \\
Carvacrol-methyl ether & 9.7 & 1164 & 3.01 \\
Thymol & 11.8 & 1288 & 84.90 \\
Carvacrol & 12.9 & 1292 & 0.41 \\
$\beta$-Caryophyllene & 15.1 & 1418 & 1.17 \\
Total identified & & & 97.82
\end{tabular}

${ }^{*}$ KI: Kovat's index; relative retention index: n-alkanes were used as reference points in the calculation of relative retention indexes. RT: Retention time.

scoparioides Benth. and Lippia origanoides H.B.K. also found that thymol was the main constituent of these oils being found in a percentage of de $23.85 \%, 20.6 \%$ and $64.8 \%$, respectively. Taking into account the citation from Leal et al. (2003) reporting that the content of thymol in L. sidoides essential, has varied in the range between 34.2 to $95.1 \%$, one can infer that L. sidoides grown in Cariri Ceará have the potential to produce high concentration of this active principle. For the same species, Sousa et al. (2004) report that different monoterpenes were detected as major constituents from sampling in two distinct areas. Individuals grown in Fortaleza (CE) produced more thymol and the ones in Apodi (RN) the carvacrol.

With respect to the analysis of the allelopathic activity, the interaction between the factors species and concentrations of essential oil was not significant between the variables studied, moving to study the isolated effect of each factor. The concentration of essential oil affected only the mean germination time. For all variables analyzed, the average of the species differed significantly (Table 2). The effect of concentration of essential oil of $L$. sidoides on the mean germination time is represented by a quadratic regression (Figure 1). The highest concentration of essential oil $\left(1.0 \mathrm{~mL} \mathrm{~L}^{-1}\right)$ caused higher mean germination time (5.4 d) with an increase of approximately $63 \%$ when compared with control.

Taking into account that the monoterpene thymol was found in highest concentration in the essential oil of $L$. sidoides, it is the possible responsible for the increase of MTG of the vegetable seeds evaluated. This negative allelopathic effect may be explained by the fact that in the process of germination of the species studied, along with the water penetrated some allelopathic substances (thymol) present in the essential oil that can inhibit or

Table 2. Summary of ANOVA of agronomic variables for the three species submitted to different concentrations of essential oil from Lippia sidoides.

\begin{tabular}{lcccc}
\hline \multirow{2}{*}{$\begin{array}{l}\text { Source of } \\
\text { variation }\end{array}$} & $\begin{array}{c}\text { Degrees of } \\
\text { freedom }\end{array}$ & EVI & GP & MTG \\
\cline { 3 - 5 } Block & 2 & $2.53^{\text {ns }}$ & $229.33^{\text {ns }}$ & $0.07^{\text {ns }}$ \\
C & 3 & $2.70^{\text {ns }}$ & $37.18^{\text {ns }}$ & $0.08^{*}$ \\
S & 2 & $251.36^{* *}$ & $13465^{* *}$ & $1.36^{* *}$ \\
C $*$ S & 6 & $2.29^{\text {ns }}$ & $124.29^{\text {ns }}$ & $0.05^{\text {ns }}$ \\
Residue & 22 & 1.56 & 70.79 & 0.02 \\
CV, $\%$ & & 25.25 & 13.5 & 34.15 \\
\hline
\end{tabular}

C: concentrations of essential oil ( $\left.\mathrm{mL} \mathrm{L}^{-1}\right)$; S: species; EVI: emergency velocity index; GP: germination percentage; MTG: mean time to germination (d); ns: non significant; ${ }^{*} \mathrm{p}<0.05$; ${ }_{* * *}^{*} \mathrm{p}<0.01$ by $\mathrm{F}$ test. 


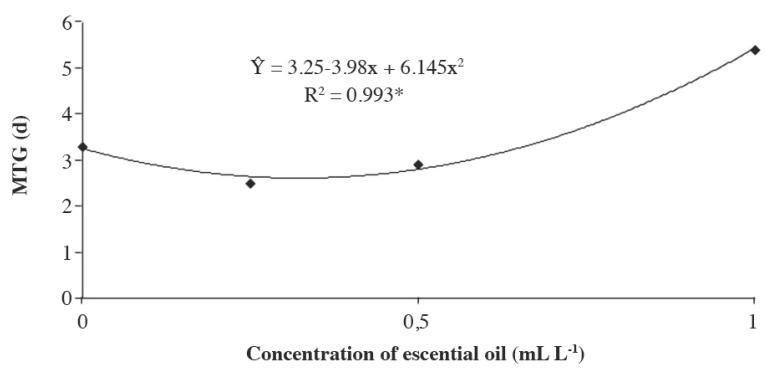

Figure 1. Mean time to germination (MTG) as a function of concentration of essential oil from Lippia sidoides. Juazeiro do Norte, Ceará, Brazil, 2009.

retard the proliferation or growth of cells, may also delay germination. According to Ferreira and Áquila (2000), often the allelopathic effect does not occur on germination, but on the germination rate or other process parameter, so the monitoring of germination must be daily. The authors mention that these changes in the pattern of germination may result from effects on membrane permeability, DNA transcription, and RNA translation, the operation of secondary messengers, breathing for the abduction of oxygen (phenol), the conformation of enzymes and receivers, or alternatively, the combination of these factors.

Gadelha et al. (2003) observed allelopathic effect of $L$. sidoides oil on the germination of lettuce seeds with a concentration equal or higher than $0.1 \%$, presenting a quadratic response and a coefficient of 0.73 by regression analysis.

Using an aqueous extract of $L$. sidoides as an alternative method to control Cyperus rotundus L., Silveira et al. (2010) concluded that the extract significantly decreased the percentage of emergence and EVI, being required new studies to elucidate the chemical principles involved and their real action in plant metabolism. Table 3 shows the average estimate of the variables (EVI, GP, and MTG) with mean comparison for the three species of vegetables. The analysis of results reveal that the average estimate of EVI for the species, arugula had a higher average, followed by cauliflower and lettuce with the average of the first species being ten times higher compared with the last one. One factor that may have influenced lettuce to present a low EVI, was the presence of monoterpene thymol (responsible for the phytotoxic effect on seed and early growth of seedlings of lettuce) attributed to intrinsic crop characteristics. These results are supported by von

Table 3. Average estimates of the emergence velocity index (EVI), germination percentage (GP), and mean time to germination (MTG) for the species arugula, cauliflower, and lettuce. Juazeiro do Norte, Ceará.

\begin{tabular}{lrrc}
\hline Species & EVI & GP $(\%)$ & MTG $(d)$ \\
\hline Rúcula & $10.00 \mathrm{a}$ & $91.33 \mathrm{a}$ & $5.44 \mathrm{a}$ \\
Couve & $3.75 \mathrm{~b}$ & $70.00 \mathrm{~b}$ & $3.95 \mathrm{a}$ \\
Alface & $1.08 \mathrm{c}$ & $25.66 \mathrm{c}$ & $1.17 \mathrm{~b}$ \\
\hline
\end{tabular}

Means follow by the same letter on columns have no difference according to Tukey test $(\mathrm{P}>0.05)$.
Poser et al. (1996), in describing that monoterpene vapors can cause anatomical and physiological changes in lettuce seedlings.

Results obtained by Menezes et al. (2000) show that in the presence of light, lettuce germination and early development occur in a wide range of temperatures with $20{ }^{\circ} \mathrm{C}$ being the best. The temperature of $35^{\circ} \mathrm{C}$ induces secondary dormancy. Corroborating with the first author, Nascimento and Cantliffe (2002), working with lettuce seeds, say that conditioning at suboptimal temperatures, lettuce seeds can reduce germination at low values.

The GP were not influenced by the concentration of essential oil used. Arugula had a higher mean value relative to cauliflower and lettuce. Although a higher number of arugula seeds have germinated in relation to other leafy vegetables, one can see that the seeds of this crop presented a lower vigor since it took more time to germinate. Lettuce crop showed inverse relation to arugula (Table 3). Silva et al. (2009) working with germination and vigor of green onions and arugula seeds found that arugula seeds presented superior germination velocity index and emergence.

\section{CONCLUSIONS}

The essential oil of $L$. sidoides showed approximately seven chemical constituents, being thymol the constituent with highest concentration (84.90\%). The essential oil of L. sidoides showed allelopathic inhibitory potential only on the mean time to germination of the studied species. Among the vegetables, arugula had a higher emergency velocity index and higher germination percentage. The average time to germination of arugula seeds was greater than that of lettuce, which had the lowest emergency velocity index and germination percentage.

\section{ACKNOWLEDGEMENTS}

We acknowledge the Laboratório de Pesquisa de Produtos Naturais, Universidade Regional do Cariri/URCA.

Composición química y actividad alelopática del aceite esencial de Lippia sidoides Cham. La alelopatía es un proceso mediante el cual productos metabólicos secundarios, tales como terpenos fenoles, producidos por una planta en particular interfieren significativamente, y de manera antagónica, en el desarrollo de otras especies vegetales. Nuestros objetivos fueron caracterizar químicamente el aceite esencial de Lippia sidoides Cham., cultivada en la región de Cariri Ceará, y evaluar el efecto alelopático del aceite aplicado en pre-siembra en la germinación de lechuga (Lactuca sativa L.), rúcula (Eruca sativa Mill.), y col rizada (Brassica oleracea L.). El principal constituyente del aceite esencial fue el monoterpeno timol $(84,90 \%)$. Los experimentos fueron conducidos en bloques completos al azar en 
esquema factorial $4 \times 3$ con cuatro combinaciones de aceites esenciales aplicados en tres especies diferentes en pre-siembra. Se analizaron las siguientes variables: índice de velocidad de emergencia (EVI), porcentaje de germinación y el tiempo medio de germinación (MTG), los recuentos se llevaron a cabo todos los días hasta el decimocuarto día después de la siembra. A través de análisis cualitativos realizados por cromatografía de gases acoplada a espectrometría de masas (GC/ $\mathrm{ME)}$ fueron identificados componentes químicos que representan 97,82\% del aceite esencial de L. sidoides, siendo constituyente más concentrado timol (84,90\%). Se comprobaron efectos alelopáticos negativos en lechuga, debido a que ésta mostró un bajo EVI y un alto MTG.

Palabras clave: alelopatía, aceites vegetales, Lippia sidoides, Lactuca sativa, Eruca sativa, Brassica oleracea.

\section{LITERATURE CITED}

Adams, R.P. 2001. Identification of essential oils components by gas chromatography/quadruple mass spectroscopy. $455 \mathrm{p} .4^{\text {th }}$ ed. Allured Publishing Corporation, Carol Stream, Illinois, USA.

Alencar, J.W., A.A. Craveiro, F.J.A. Matos, and M.I. Machado. 1990. Kovats indices simulation in essential oils analysis. Química Nova 13:282-284.

Alves, S.M., M.S.P.Arruda, and A.P.S. Souza Filho. 2002. Biossíntese e distribuição de substâncias alelopáticas. p. 79-102. In Souza Filho, A.P., and S.M. Alves (eds.) Alelopatia: Princípios básicos e aspectos gerais. EMBRAPA, Belém, Amazônia Oriental, Brasil.

Alves, M.C.S., M.F. Sebastião, e I.S.B.T. Renato. 2004. Alelopatia de extratos voláteis na germinação de sementes e no comprimento da raiz de alface. Pesquisa Agropecuaria Brasileira 39:1083-1086.

Botelho, M.A., N.A.P. Nogueira, G.M. Bastos, S.G.C. Fonseca, T.L.G. Lemos, F.J.A. Matos, et al. 2007. Antimicrobial activity of the essential oil from Lippia sidoides, carvacrol and thymol against oral pathogens. Brazilian Journal of Medical and Biological Research 40:349-356.

Carvalho, A.F.U., V.M.M. Melo, A.A. Craveiro, M.I.L.M. Machado, M.B. Bantim, and E.F. Rabelo. 2003. Larvicidal activity of the essential oil from Lippia sidoides Cham. against Aedes aegypti Linn. Memórias do Instituto Oswaldo Cruz 98:569-571.

Costa, S.M.O., T.L.G.L. Lemos, O.D.L. Pessoa, C. Pessoa, R.C. Montenegro, and R. Braz Filho. 2001. Chemical constituents from Lippia sidoides and cytotoxic activity. Journal of Natural Products 64:792-795.
Ferreira, A.G., e M.E.A. Áquila. 2000. Alelopatia: uma área emergente da ecofisiologia. Revista Brasileira de Fisiologia Vegetal 12:175-204.

Gadelha, J.C., N.S.S. Borges, I.B. Nascimento, M.A.S. Oliveira, R. Innecco, e R.S. Medeiros Filho. 2003. Efeito alelopático de alecrim pimenta na germinação e vigor de alface. Informativo Abrates 13:425-426.

Leal, L.K.A.M., V.M. Oliveira, S.M. Araruna, M.C.C. Miranda, e F.M.A. Oliveira. 2003. Análise de timol por CLAE na tintura de Lippia sidoides Cham. (alecrim-pimenta) produzida em diferentes estágios de desenvolvimento da planta. Revista Brasileira de Farmacognosia 13:9-11.

Menezes, N.L., O.S. Santos, E.P. Nunes, e D. Schmidt. 2000 Qualidade fisiológica de sementes de alface submetidas a diferentes temperaturas na presença e ausência de luz. Ciência Rural 30:941-945.

Morais, A.A. de, J.C. Mourão, O.R. Gottlieb, M. L. da Silva, M.C., Marx, J.G.S. Maia, e E.M.T. Magalhães. 2011. Óleos essenciais da Amazônia contendo thymol. Available at http://acta.inpa.gov. br/fasciculos/2-1/PDF/v2n1a09.pdf (accessed 4 October 2011).

Nascimento, W.M., e D.J. Cantliffe. 2002. Germinação de sementes de alface sob altas temperaturas. Horticultura Brasileira 20:103106.

Silva, J.P.L, J.M.D. Almeida, D.V. Perez, e D.B.G. de M. Franco. 2010. Óleo essencial de orégano: interferência da composição química na atividade frente a Salmonella enteritidis. Ciência e Tecnologia dos Alimentos 30:136-141.

Silva, W., M.F. Souza, J.F.B. Senra, E.O. Pereira, M.Q. Martins, e J.C. Lopes. 2009. Germinação e vigor das sementes de cebolinha e rúcula. Anais. In XIII Encontro Latino Americano de Iniciação Científica e IX Encontro Latino Americano de Pós-Graduação, Universidade do Vale do Paraíba. Available at http://www.inicepg. univap.br/cd/INIC_2009/anais/arquivos/RE_0898_0821_01.pdf (accessed 28 March 2011).

Silveira, H.R.O., E.O. Ferraz, C.C. Matos, I.C.A. Alvarenga, D.O. Guilherme, L.D. Tuffi Santos, e E.R. Martins. 2010. Alelopatia e homeopatia no manejo da tiririca (Cyperus rotundus L.). Planta Daninha 28:499-506.

Sousa, M.P., F.J.A. Matos, M.E.O. Matos, M.I.L. Machado, e A.A Craveiro. 2004. Constituintes químicos ativos e propriedades biológicas de plantas medicinais brasileiras. 448 p. Editora UFC, Fortaleza, Brasil.

von Poser, G.L., C. Menut, M.E. Toffoli, M. Sobral, J.M. Bessiere, G. Lamaty, and A.T. Henriques. 1996. Aromatic plants from Brazil: 4. Essential oil composition and allelopathic effect of the Brazilian Lamiaceae Hesperozygis ringens (Benth.) Epling and Hesperozygis rhododon Epling. Journal of Agricultural and Food Chemistry 44:1829-1832. 